\title{
From Hermano Lejano to Hermano Mayor: the dialectics of Salvadoran transnationalism
}

\author{
Patricia Landolt, Lilian Autler and Sonia Baires
}

\begin{abstract}
A dialectical framework is proposed for analysing the economic and political practices associated with immigrant transnationalism. The causes and consequences of the transnational relations sustained by Salvadoran migrants in Los Angeles and Washington, DC, with El Salvador is used to test this proposition. It is argued that the conditions of Salvadorans' exit from their country of origin and of their reception in the US explains their tendency to invest considerable resources in forging and maintaining transnational relations with their places of origin. In turn, the aggregate impact of household-level transnational practices elicit spontaneous and institutional responses from different sectors of Salvadoran society. Based on the case of El Salvador, typologies of transnational economic enterprises and transnational political practices are presented that confirm the high degree to which the maintenance of transnational relations are indispensable to El Salvador and its migrant-citize ns.
\end{abstract}

Keywords: Transnational migrant community; El Salvador; Salvadorans in the US; economic transnationalism; political transnationalism.

For over a century international migration has been a defining element of the Salvadoran social order. Since the 1880s permanent and cyclical regional population displacements associated with capitalist penetration have paced the life cycle of the peasant household (Browning 1971; Hamilton and Chinchilla 1991). Successive waves of élite land expropriation and concentration have propelled landless campesinos to seek seasonal labour on the plantations of Guatemala and Honduras. Others have been beckoned by wage work on the Panama Canal, while the most adventurous have gone as far as the oil rigs of the Middle East in search of survival.

Most recently, eleven years of bloody civil war (1981-1992) have prompted yet another population flow. Civil strife and its associated economic disruptions displaced over 700,000 civilians within the region and 
forced more than a million Salvadorans to seek safe haven in Canada, Australia, Europe, and the United States where the Salvadoran population is now estimated at 1.2 million (Zolberg et al. 1989; ECLA 1993). This rapid and massive flight from violence overturned established patterns of regional migration and rescripted the Salvadoran social order. As a consequence, migration is no longer the exclusive reserve of a land poor peasantry and now touches the lives of Salvadoran families across the socio-economic spectrum. Most significantly, Salvadoran migrants have overcome distance, as well as legal and economic adversity, to forge a variety of transnational relationships and commitments with their places of origin. In the process, migrants, historically associated with displacement and marginality, have unwittingly become critical agents of social change, shaping the dynamics of El Salvador's economic, political, and cultural institutions at the local, regional and national levels.

Our analysis of the Salvadoran migration process is framed as a dialogue with two central tenets of the vast and eclectic scholarship on transnationalism. First, proponents of transnationalism argue that structural changes in the world capitalist system have augmented the tendency towards transnationalism among international migrants (Glick Schiller et al. 1992; Basch et al. 1994; Guarnizo and Smith 1998). The increased internationalization of capital and global reorganization of production has produced local economic disruptions that have resulted in an increase in the world's total migrant population. In turn, more affordable travel and the diffusion of communications technology such as telephone, facsimile, and electronic mail services, developed in response to the exigencies of international capital, have enabled international migrants to sustain intense and regular ties across national borders.

The case of Salvadoran transnational migration confirms the association between structural changes at the global level and the proliferation of immigrant transnationalis m. Going beyond this broad proposition, our work focuses on the importance of distinguishing between a general world increase in transnationalism and the specific elements of the migration process that are propitious to the formation of transnational relations. Based on the case of Salvadoran transnationalism, we argue that the conditions of migrants' exit from their country of origin and of their entrance and settlement in the host society play a central role in determining the propensity, complexity and stability of transnational practices.

Scholars of transnationalism also contend that the boundaries between the home and host society erode as migrants engage simultaneously with their country of origin and reception. In fact, the circulation of goods, people and information across the sending and settlement locations leads to the emergence of a transnational social field that straddles international borders, is neither here nor there, but in a newly constructed social space (Basch et al. 1994). In turn, as social, economic and political relations and processes enter the transnational social field they are transformed as 
existing hierarchies of power are weakened and the potential for autonomous liberatory action heightened (Nagengast and Kearney 1990; Rouse 1991). The Salvadoran migration process confirms that social processes of the home and host society merge towards a single sphere of social action due to the maintenance of transnational ties. But it is our contention that neither the erosion of boundaries between social spheres, nor the circulation of resources between home and host society, necessarily results in the consolidation of a transnational sphere of social action.

We dispute the characterization of the transnational sphere of social action as inherently autonomous and contestatory and conceptualize transnationalism, or more precisely the creation of a transnational social field as a dialectical process. Grass-roots transnationalism or 'transnationalism from below' - the transnational practices of a displaced migrant population seeking economic, social and political reinsertion elicits an élite transnational response or 'transnationalism from above'. This transnational engagement prompts cumulative consequences that give rise to the transnational social field not as a liberatory social sphere of autonomous migrant action, but as a terrain in which established structures of domination and exploitation are contested, altered and reconstructed. Our analysis of the transnational economic and political practices sustained by Salvadoran immigrants and the responses they elicit from different sectors of Salvadoran society seeks to test this dialectical proposition.

Using preliminary results from an ongoing investigation conducted in El Salvador and in Los Angeles and Washington, DC, two primary Salvadoran settlements in the United States, we examine the development and consequences of the transnational practices and processes that link Salvadoran immigrants living in the United States to their country of origin. ${ }^{1}$ First, we assume a bird's-eye view to explore the structural conditions associated with both the proliferation of transnational practices among Salvadoran immigrants and the transformatory responses that these practices elicit in El Salvador at the local and national levels. Second, we present evidence of the diversity of organized economic and political practices that link El Salvador to its migrant settlements. Focusing on transnational economic enterprises and transnational political projects, we examine how these practices are becoming increasingly stable, multidimensional and inter-linked. Finally, we identify the elements that make El Salvador a unique case and the patterns identified in the case-study that can be used to analyse migrant transnationalism more broadly.

\section{Local contexts/global forces: the transformation of Salvadoran migration}

In just under two decades, 20 per cent of El Salvador's citizens, or one in every five persons, has exited the country. The long-term impact of this 
flight from violence has been transformatory as different sectors of Salvadoran society adjust to the crucial role that migration now plays in national affairs. Salvadoran banks scramble to capture remittance dollars, consular programmes are launched to protect the rights of the nation's hermanos lejanos or distant migrant-brothers, while the sites, sounds and smells of Los Angeles, Washington, Houston and Hempstead make their way into El Salvador, penetrating to the very roots of this mestizo and campesino nation.

The ubiquity of the migration experience is confirmed by the diversity of the Salvadoran population in the US. Serving as a historic hub of Salvadoran migration, Los Angeles is home to a representative crosssection of Salvadoran society. A large proportion of the estimated 300 to 500,000 Salvadoran Angelenos is of working-class or campesino origin, but there is also a substantial and growing middle and upper-middle class. The breadth of social clubs in Los Angeles, typically agglutinated around home town allegiances, also reveals that Salvadorans in this metropolis come from all regions of El Salvador. The Salvadoran population of Washington, DC, and its contiguous beltway cities in Virginia and Maryland is estimated to be 250,000 (US Census 1992). Its composition is slightly more homogeneous than that of Salvadorans in Los Angeles, with the overwhelming majority being campesinos from the war-torn region of oriente.

\section{A preferential option for transnational settlement}

It is axiomatic of the migration process that new immigrants will employ scarce resources to maintain ties with family and friends in their country of origin. In the case of Salvadorans, this universal need to maintain transnational ties was heightened by the circumstances of migrants' exit from El Salvador and the context of their reception in the United States. Salvadorans' departure was immersed in the uncertainties of war time and, consequently, also in strong normative expectations about the impermanent nature of their exodus. The socially expected duration of their migration, in other words Salvadoran migrants' imagine of themselves as sojourners and not as immigrants fated to settle in the US, necessarily shaped their behaviour (Merton 1984; Roberts 1995). In effect, this temporal expectation coupled with the violence, chaos and poverty in which migrants left their families in El Salvador, endowed them with a deep sense of social obligation towards their places of origin.

Likewise, a cold reception from the receiving society accentuated migrants' need to maintain links with their home land. Salvadorans, like all immigrants entering the US in the 1980s, settled in urban centres in the throws of economic restructuring, recession and fiscal crisis. Newcomers also encountered a xenophobic political climate and, in the particular case of Salvadorans, a hostile federal government. Given the 


\section{Patricia Landolt et al.}

Reagan Administration's support for the Salvadoran government, it refused to recognize Salvadorans as legitimate refugees (StantonRussell 1995). Indeed, the prejudicial treatment of Salvadoran asylumseekers resulted in a legal battle against the state, led and won by the American Baptist Church [ABC], a leader in the Sanctuary Movement that during the 1980s offered Central American refugees safe haven. This legal victory was instrumental in shifting the government's response to Salvadorans' claim to refugee status and resulted in the granting of temporary protected status [TPS] between 1991 and 1994 (Zlotnik 1996). In spite of this policy shift, the government's legal offensive has kept Salvadorans in a precarious legal limbo for close on two decades. The combined effect of economic adversities, political hostilities and legal instability has been to convince migrants of the need to keep a toehold in El Salvador as a safety net against possible deportation or financial difficulties in the US.

The case of Salvadoran migrants confirms Portes and Rumbaut's (1997) proposition that the social context in the host society, or reception levels such as public opinion and government policy, conditions the settlement process of an immigrant group. In this case, Salvadoran migrants' desire to meet familial responsibilities, and their need for minimal guarantees in the face of legal and economic uncertainty in the US, translates into the construction of a transnational frame of reference for household decision-making. Their preferential option for transnational over local strategies of economic and social incorporation results from a confluence of local and global factors. The uncertainties of war and a negative reception in the US conspire to push migrants to maintain ties with their place of origin at a time when the dynamics of the world capitalist system make the maintenance of transnational relations feasible and thus transnational households surprisingly functional.

\section{The distant brother comes home: from aggregate impact to purposive action}

The most routine expressions of Salvadoran migrants' transnation al obligations, for instance, the sending of family remittances and investment in real estate, have had an astounding aggregate impact on El Salvador. At the national level, family remittances have served as a cushion for a stagnant economy. During the 1980s, the flow of remittances never fell below US $\$ 600$ million and consistently equalled the country's export earnings. In the 1990s remittances continued to increase. In 1996 they totalled approximately $\$ 1.26$ billion, thereby offsetting much of the country's trade imbalance (Caribbean Update 1996).

The recent history of San Miguel demonstrates how household-level transnational obligations snowball and take on a transformatory life of 
their own. With the outbreak of the civil war, San Miguel's entrepreneurs and landed élite abandoned their investments and withdrew to the relative safety of San Salvador. The local economy collapsed and the city was overrun by campesinos fleeing the violence of the countryside. Many of them later migrated to the United States. In the 1990s, after lying dormant for close on a decade, a short-lived surge in migrant remittances associated with the signing of the Peace Accords and the threat of mass deportations from the US jolted San Miguel back to life. The city enjoyed unprecedented economic growth as migrants launched small businesses and purchased real estate in single cash payments. Investors, including the nation's banks, department stores and professionals, descended upon San Miguel in their pursuit of migrant dollars. Salvadoran migrant households' decision to repatriate cash savings produced an illusion of wealth that, like a vortex, drew all sectors of Salvadoran society towards its centre. A fictitious economy, based solely on the circulation of remittance money, forced a disregard for the simple post-war fact that San Miguel produces absolutely nothing.

The economic weight of migrants in the national economy has also inspired new government policy initiatives, as well as a shift in investment strategies by the private sector. In an effort to channel family remittances through formal banking institutions, the Central Reserve Bank of El Salvador [BCR] authorized Salvadoran banks with branches in the US (the Banco Cuscatlán and the Banco Salvadore o) to serve as remittance agencies. To date though, only between $\$ 8$ to $\$ 10$ million of an estimated $\$ 1$ billion in annual remittances are wired this way. The BCR, in consultation with the World Bank, also launched a short-lived investment programme that allowed recipients of family remittances to access small business loans. Likewise, Salvadoran immigrant settlements have been the testing ground for new marketing strategies by industries and of investment and expansion by Salvadoran manufacturing firms. This mixed assemblage of economic policies and strategies signals Salvadoran capital's recognition of the central role that the resources of Salvadoran migrants now play in the national economy.

Salvadoran migrants' transnational practices are not strictly economic in nature and have extended beyond household level concerns. In the late seventies, Salvadoran immigrants were instrumental in the creation of the international solidarity and lobbying networks of El Salvador's guerilla opposition, the Frente Farabundo Martí para la Liberación Nacional [FMLN] (Gosse 1996). With the end of the war, this transnational network has atrophied. But out of the experiences of the 1980s have emerged new political and social actors committed to a transnational social justice and community development agenda that embodies the distinct vision of the Salvadoran migrant citizenry. This new transnational voice includes student exchange programmes for Salvadoran-American youth, a transnational credit union, and home town 
associations whose members raise funds for improvement projects in their towns of origin.

As a consequence of their political fervour, in the post-war climate of reticent reconciliation and under-funded reconstruction, Salvadoran migrants' organized transnational practices have sparked great interest and concern. The nation's established political players - the FMLN and the government of El Salvador - have had to reconsider their political strategies in the light of the rise to prominence of these new political actors. The government has initiated a series of transnational campaigns to breach the institutional distance between a distrusted and often feared ARENA party government and the nation's migrant-citizens. Likewise, the FMLN has had to confront the political challenges and demands for equality coming from its migrant membership. At the local level, the resources garnered by home town associations have encouraged municipal leaders to hold dialogues with their transnational townsfolk. El Salvador's established political actors must now recognize and engage with a heterogeneous migrant voice represented by organizations that cross the social and political spectrum.

To summarize, the impact of household-level transnational practices on El Salvador prompts Salvadoran society to engage spontaneously and institutionally in a variety of ways with the nation's migrant-citizens. The emergence of a transnational relationship between Salvadoran migrants and different socio-economic and political voices in Salvadoran society has several related and overlapping effects. It leads, first, to the consolidation of migrants as a central component in the national economy; second, to their establishment as critical agents of social, political and cultural change; and, finally, and incipiently, to their emergence as a new, unified, albeit heterogeneo us voice in national affairs.

\section{Economic transnationalism}

Statistical indicators of the Salvadoran population in the US paint a troubling picture of poverty and social malaise (Mahler 1995; Repak 1995; López et al. 1997). A significant proportion of Salvadoran immigrants labour in the unregulated, low-wage service sector of the urban economy, and constitute part of the United States's working poor. The transnational practices of this population are limited to sending family remittances that simply enable households to meet their minimum consumptive requirements. But this rather grim picture of Salvadoran immigrants is incomplete. Our field research in Washington, DC, and Los Angeles also unearthed a vibrant entrepreneurial economy embedded in a web of transnational relations.

The potential for innovative social change inherent in entrepreneurship informs our inquiry into Salvadoran economic transnationalism. We examine two aspects of transnation al entrepreneurship. First, we develop 
a typology of the transnational enterprises that bind El Salvador to the Salvadoran settlements of Los Angeles and Washington, DC, and map the flow of transactions between these different types of transnational enterprises. Second, we present social profiles of transnational migrant entrepreneurs and chart their place in local and transnational structures of power.

\section{Mapping the flows of transnational enterprises}

There is a thriving formal and informal commerce of goods and services between El Salvador and the Salvadoran settlements of Los Angeles and Washington, DC, that is sustained by micro, small, and medium-size transnational enterprises. In order to present a cogent picture of this panoply of business ventures, we have categorized formal and informal enterprises located both in the US and in El Salvador, regardless of their size, according to their transnational dimensions. The typology isolates the transnational aspects of the production and consumption process (that is, investment and expansion capital, inputs, labour, consumer market) in order to establish the extent to which transnational ties are, indeed, an essential part of Salvadoran immigrant entrepreneurship. Below, we identify and describe five types of enterprises for which the maintenance of transnational links is important.

Born of the migration process, circuit enterprises are the archetypical transnational business venture because they sustain the flow of tangible and intangible resources between a country of origin and its migrant settlements. In the case of El Salvador, circuit enterprises were first established during the civil war. Migrants' need to sustain regular contact with relatives in El Salvador gave rise to an army of informal couriers who shuttled back and forth delivering letters, cash, and precious packages. From these small and informal beginnings was born a complex, multi-million dollar service industry. The rapid circulation of goods and information between Salvadoran settlements in the US and El Salvador ensures that these two locations function virtually as a single unit. Spacetime has been effectively compressed (Harvey 1989).

Currently, circuit enterprises include informal and formal courier agencies that deliver money, products, and people using a variety of methods to households and businesses in both countries. But the most ubiquitous of couriers is still the original viajero or traveller who shuttles between El Salvador and the US delivering cash, letters and gifts, and importing unregulated Salvadoran comestibles and contraband such as antibiotics to households, family-run businesses, and even to large enterprises and retail stores in the US.

Viajeros compete for the transnational market with formal delivery and remittance agencies, such as the Salvadoran financial power house Gigante Express. Facing formidable competitors, viajeros must rely on 


\section{Patricia Landolt et al.}

their social networks, personalized service and flexibility to survive. For instance, viajeros gain the trust of their clients not only through prompt delivery, but also as they advance packages without payment, read letters for the illiterate, and recount how family members abroad are faring. Ironically, these most informal of transnational entrepreneurs also depend on TACA, the Salvadoran airline and perhaps the nation's largest multinational enterprise, to sustain their transnational circuit. Until recently, TACA has had an unspoken agreement with viajeros that enables them to travel unhindered on TACA flights. But, facing pressure from a Salvadoran government interested in regulating this informal transnational commerce, TACA has begun to place merchandise and quantity restrictions on viajeros that threaten their survival.

We refer to the second type of transnational enterprise as cultural enterprises because of their tacit role as stewards and promoters of national identity among Salvadoran immigrants. Cultural enterprises are based in Salvadoran settlements in the US, rely on their daily contact with El Salvador, and depend on migrants' desire to consume Salvadoranness for their market. Cultural enterprises include both ventures that produce or distribute Salvadoran mass media such as newspapers, radio and TV programming, and businesses that produce or distribute Salvadoran beverages and comestibles.

Newsprint media is perhaps the most prolific cultural enterprise. El Salvador's national dailies are readily available in Los Angeles and Washington, DC, and a variety of locally edited newspapers including an internet magazine (three in LA and two in DC) have also been founded since 1992. The latter typically maintain an office and staff in El Salvador and rely on their contacts with the Salvadoran government and private sector for newsworthy information and to fill their advertising pages. In both LA. and DC, the papers are owned by entrepreneurs with significant business investments in the US and El Salvador. The owners and directors of the newspapers represent different tendencies within Salvadoran right-wing politics, and often use the newspapers not only to promote their businesses, but also to advance their political interests.

We have labelled the third type of transnational business venture ethnic enterprises. They include an assortment of small business ventures located in immigrant neighbourhoods of Salvadoran concentration that employ Salvadorans exclusively, but that cater to a broadly ethnic clientele (African, Asian and Latin American). In both Los Angeles and Washington, DC, the typical ethnic enterprises are small grocery or convenience stores, restaurants and bakeries, retail commerce, beauty shops, auto mechanics, and crafts people such as carpenters and plumbers, as well as informal street vendors. Given the larger concentration of Salvadorans in Los Angeles, this settlement's ethnic enterprise sector is more vibrant and diverse. It also has more transnational links than its Washington, DC, counterpart. While many ethnic enterprises in Los Angeles 
depend on a steady supply of regulated and unregulated imports from El Salvador, businesses in DC maintain only sporadic and often superfluous transnational supply networks.

The fourth type of transnational enterprise is the business ventures of 'return' migrants located in El Salvador. The most common types of return migrant micro-enterprises include restaurants that offer Tex-Mex or Chinese dishes, automobile related activities such as transport services (taxis, bus lines and delivery trucks), new and used vehicle sales, maintenance and repairs, as well as commerce (used and new clothing, electrical appliances) and services (laundromats, and fax/photocopy). Return migrant business ventures depend on transnational links and flows for their investment capital, human capital, maintenance costs and expansion capital (Baires and Innocenti 1993). Typically, the idea for a microenterprise originates with the migrant's cultural and labour experience in the United States, and the investment capital comes from the migrant's personal savings. Given the precarious and often low rentability of their business ventures, expansion and maintenance costs often force the entrepreneur to seek wage-work in the United States on a regular basis. Given the incapacity to accumulate capital, the so-called return migrant entrepreneur's migration cycle is rarely broken, challenging the conceptual distinction between permanent, return and cyclical migration.

The fifth and final form of transnational enterprises are what we refer to as expansion enterprises. Transnational expansion enterprises include both established Salvadoran companies and new business ventures that conceive of the Salvadoran immigrant market as part of El Salvador's natural market. The former includes large firms such as the Constancia Bottling Company that has a production plant in Los Angeles and a sales office in Washington, DC, and the Tapachulteca Supermarket that also has a franchise in LA. Among the latter, the most interesting example is the Corporation for the Promotion of Small and Medium Enterprise [CORPRIME].

The strategy of CORPRIME is ground breaking because it fuses the post-1970s fragmented global production paradigm with the opportunities for transnational expansion and profit created by the Salvadoran migration process. CORPRIME was founded in 1996 by an eclectic group of entrepreneurs including key members of El Salvador's National Association of Private Enterprise [ANEP], the Salvadoran Chamber of Commerce and Industry [CCIS], and return migrant entrepreneurs who had lived in the United States for many years. The CORPRIME organizes existing small and medium artisanal enterprises in El Salvador into systems of cluster production following the model of Emilia Romagna, Italy (for an analysis of this model see Vittorio 1989). They produce items, such as leather goods, to suit the taste of Salvadoran and Mexican immigrants in California. CORPRIME's first project was the production of cowboy boots for which Mexico provided the soles, Nicaragua the 
leather and El Salvador the artisan labour. Capitalizing on its contacts in Los Angeles and the bicultural business acumen of its founding investors, CORPRIME has been able to develop a marketing and distribution strategy in tune with California's Latino market.

Transnational expansion enterprises represent an important shift in the flows of international capital. In essence, the existence of a Salvadoran immigrant market with distinctly Salvadoran consumption preferences permits capital from the periphery to penetrate the core. Prior to the formation of a Salvadoran settlement in Los Angeles, neither CORPRIME's cowboy boots nor Constancia's beer and sodas could have competed with the products of established US name brands. Due to the existence of immigrant settlements with strong cultural and social bonds to El Salvador, these firms are able to enter this small, culturally specific market niche based on a strategy that we refer to as 'targeted globalization'.

Table 1 reviews the five types of transnational enterprises that we have identified. This heuristic presentation will facilitate further comparative discussion of the diverse forms of economic transnationlism that bind small nations of the periphery to their migrant settlements in the US. The typology draws attention to how different types of enterprises vary in the degree to which they depend on transnational contacts and exchanges. In a straight forward fashion, it suggests that circuit enterprises and transnational expansion enterprises are most dependent on transnational exchanges, whereas ethnic enterprises are the least dependent.

Within this general proposition, the typology also draws out more specific dimensions of Salvadoran economic transnationalism. Formal and informal enterprises are bound together by relations of articulation and competition. For instance, informal viajeros survive because they are able to deliver produce to ethnic enterprises in the US due to the permissive policy of TACA airlines, but face fierce competition from remittance agencies like Gigante Express. This cursory examination into a diverse panoply of transnational firms also substantiates the proposition that the economic logic of transnational migrant enterprises shadows that of large global corporations (Portes 1995). The profitability of transnational enterprises, whether it is sought by a transnational household or a manufacturing industry facing a saturated local market, is indeed grounded on the differentials of advantage created by political boundaries.

Transnational migrant entrepreneurship: social mobility, power, and status

Entrepreneurship remains the privileged domain of a small sub-group of the Salvadoran immigrant population. Informants in Los Angeles and Washington, DC, calculate that no more than 10 per cent of the 


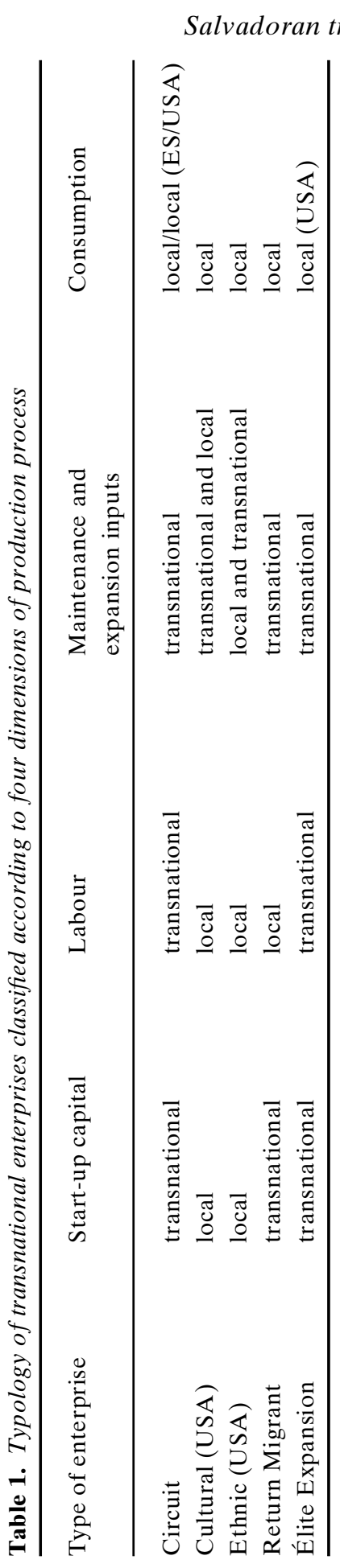




\section{Patricia Landolt et al.}

Salvadoran immigrant population is self-employed and that a large proportion of the self-employed are merely supplementing their meagre wage earnings by moonlighting in the informal sector. Hence, the number of successful entrepreneurs who can parlay wealth into social influence and status is, as in all social groups, quite reduced.

None the less, the existence of Salvadoran entreprene urs is significant because it challenges the notion of Salvadoran immigrants as a homogeneous group of uneducated, low-wage labourers drifting in a hostile sea of deregulated sweatshops and undocumented anonymity. Entrepreneurship presumes mechanisms of financial and administrative support, as well as a wealth of resources, knowledge and expertise. The existence of entrepreneurs also suggests that the Salvadoran immigrant population is internally differentiated along economic lines, and logically then, also by differences in status, power and influence. Below we construct social profiles of transnational migrant entrepreneurs, mapping the connections and relations between sectors and their respective spheres of influence. We examine the extent to which transnational entrepreneurship grants migrants not simply wealth but also social and political acceptance among established business élites in both the US and El Salvador.

El Salvador's informal circuit couriers, such as viajeros, and return migrant business people constitute the most prolific but also the most vulnerable group of transnational migrant entrepreneurs. The fortunes of their business ventures are inextricably bound both to the planned and unexpected requirements of their household. For instance, women viajeros, of which there are many, tend to enter and exit the transnational circuit in response to the needs of their household. Likewise, return migrant micro-entrepreneurs are forced to return to wage-work in the US because, for instance, of a family emergency. There is no administrative or financial distinction between the household and the meagre profits of the micro-enterprise, and consequently little likelihood of selfgenerated capital accumulation and growth.

In addition to these internally generated limitations, there are externally imposed barriers. There are, for instance, few assistance programmes for migrant micro-enterprises in El Salvador. Microentrepreneurs claim they face cut-throat competition and institutional hostility, such as anti-migrant and partisan prejudice at loan agencies, that make economic survival almost impossible. To date, although grassroots entrepreneurs have had a massive and volatile aggregate impact on the Salvadoran economy, as evidenced by the case of San Miguel, they have made few institutionalized inroads into El Salvador's economic power structure.

A diversity of ethnic entrepreneurs based in Salvadoran settlements in the US constitute a second group of transnational migrant entrepreneurs. Here, we consider only the most prominent ethnic entrepreneurs of Washington, DC, and Los Angeles. In the case of Washington, DC, this 
sector is constituted by just a handful of men and women of humble origins who arrived in the US with very little and who have built up small fortunes. First investing in small restaurants and commercial establishments in the Salvadoran neighbourhood of DC called Mount Pleasant, they have expanded into the contiguous suburban towns of Maryland and Virginia following the expansion of the Salvadoran population into these areas. In contrast, the Salvadoran ethnic entrepreneurs of Los Angeles are a much more heterogeneous group both in terms of their class background, and the types of business ventures they have established.

The differences between the ethnic entrepreneurs of Los Angeles and Washington, DC, become more apparent when their respective position in local and transnational associations is considered. In spite of their considerable wealth and entrepreneurial enthusiasm, Washington's Salvadoran entrepreneurs are largely absent from local business associations. Their participation in the local Hispanic Chamber of Commerce, the Greater Washington Ibero-American Chamber of Commerce, organizations dominated by more affluent and established Hispanics such as Cubans and Venezuelans, and in the neighbourhood oriented Mount Pleasant Business Association, is negligible. Rather than push for membership in existing business associations, Salvadoran entrepreneurs in Washington, DC, have developed independent organizations more suited to their transnational concerns. Since the mid-eighties, they have twice founded business associations in DC whose main goal has been to fundraise for charitable organizations in El Salvador. Both efforts are basically defunct because, according to informants, the organizations were too politicized and thus failed to gain wide acceptance among Salvadorans.

Where DC's entrepreneurs have met with incredible success is in the formation of local chapters of home town associations, and the parallel sponsorship of large and well attended cultural and sports events both in DC and in their towns of origin. These socially oriented activities have not granted Salvadoran entrepreneurs entrance into Washington, DC's mainstream or its Hispanic business élite. But they have served as an important platform from which they exercise power and influence not only over the Salvadoran immigrant population in DC but also over their towns of origin. In particular, fieldwork in El Salvador confirmed that while these self-made men and women may be small fish in DC in the little ponds that constitute their towns of origin they are definitely big fish. This begins to explain why entrepreneurs have opted to construct and develop transnational rather than local spheres of influence.

The sphere of influence of ethnic entrepreneurs in Los Angeles stands in sharp contrast to that of their counterparts in Washington, DC. One of the main differences is that transnational entrepreneurship in Los Angeles is over determined by the institutional presence of the Salvadoran bourgeoisie through the Salvadoran Chamber of Commerce and 
Industry [CCIS]. Salvadoran ethnic entrepreneurs serve as a conduit between the Salvadoran market and Salvadoran companies expanding into this consumer group. For example, CORPRIME and CASALCO have relied both on the Salvadoran Consulate of Los Angeles and on the CCIS and its contacts among Salvadoran entrepreneurs to pitch their products (cowboy boots and real estate) in LA. Thus, to the extent that Salvadoran entrepreneurs in Los Angeles have emerged as an organized business voice this has occurred in conjunction with their deepening involvement with the CCIS and the Salvadoran Consulate.

Our analysis of the economic ties that bind El Salvador to Salvadoran settlements in the US suggest that there is a marked difference between economic transnationalism and transnational migrant entrepreneurship. The former is a broad structural process that can, as the case of El Salvador suggests, envelop and transform a migrant-sending nation of the periphery. The latter is an avenue for individual social mobility shaped by factors such as the human and material resources of the immigrant group and the characteristics of the economy of the country of origin. In the case of El Salvador, transnational migrant entrepreneurship is too disparate, informal and lacks the wealth and institutional representation required to challenge effectively the rigidities and logic of exclusion that constitute the guarded gates of capital in small nations of the periphery. In the absence of dynamic transnational firm formation from below, the hermano lejanos' consumption power and the transnational expansion strategies of the Salvadoran élite become the principal determinants of the contours of economic transnationalism.

\section{Political transnationalism}

Contemporary Salvadoran migration has been inherently politicized. As the civil war gave rise to mass migration, it also led to an association between politics and violence in El Salvador. Transnational political relations have mirrored these partisan conflicts. As such, during the war the government viewed those who fled the violence as subversives and consequently relations between itself and Salvadoran immigrants and refugees in the US were negligible, if not hostile. In the absence of the Salvadoran government from the transnational arena, transnational political relations were monopolized by the FMLN. Organizations such as CARECEN and El Rescate that were affiliated with the different factions of the FMLN advocated on behalf of Salvadoran migrants, denounced the US foreign policy in Central America, and condemned human rights abuses in El Salvador. Logically, under these conditions, there were few spaces for non-partisan, transnational civic engagement.

In 1992 the government of El Salvador and the FMLN signed the United Nations's brokered Peace Accords of Chapultepec, thus ending a civil war that had claimed over 80,000 lives. The process of national 
reconstruction and reconciliation that followed has brought about dramatic changes in the political landscape of El Salvador, its migrant settlements, and the transnational ties that bind the two. Ideological polarization has grown less stark, and political spaces, once sharply defined and defended with force, are now more openly contested. In this less polarized environment, a panoply of new transnational political voices has begun to emerge. The post-war transnational migrant voice is constituted both out of the ashes of existing organizations and by ordinary Salvadoran immigrants who have never before participated in politics. Together these organizations constitute Salvadoran migrants' transnational field of social and political engagement.

Our discussion of political transnationalism builds on the basic conceptual framework of transnationalism as a dialectical engagement of grass roots and élites. First, we consider the multiple projects that constitute El Salvador's transnational grass-roots movement including both those groups seeking meaningful ways to influence the course of development and change in El Salvador and those concerned with improving the condition of Salvadoran immigrants in the US. We then examine the new transnational roles and practices being adopted by El Salvador's established political players - the FMLN and the national government - in response to these grass-roots initiatives.

\section{Transnational grass-roots civic action}

The Peace Accords ruptured existing transnational networks, tested transnational alliances, and rewrote the possibilities for transnational political engagement and citizen participation. The institutionalization of the FMLN as a political party in El Salvador fragmented the only political links that until 1992 had tied Salvadoran immigrants to their homeland. Following the initial shock, this political vacuum has slowly been filled by multiple innovative forms of transnational civic engagement that seek to influence the political future of El Salvador, either by working with and helping to transform existing community based social justice organizations, or by creating new ones.

El Salvador's post-war transnational civic initiatives fall into two categories: partisan and autonomous. The former includes organizations originally created to serve the international solidarity agenda of El Salvador's established political players, and particularly the war-time agenda of the FMLN. The latter includes self-generated immigrant groups that often work with, but distinguish themselves from, openly partisan associations. Below, we discuss first the post-war transformation of the partisan organizations previously affiliated with the FMLN and then examine two types of autonomous organizations that have proliferated since the signing of the Peace Accords.

Cut loose from the strategic needs of the FMLN in 1992, partisan 
organizations such as CARECEN and El Rescate that had played a very clear transnational role during the 1980s were forced to re-define themselves and their mission. Both organizations turned their attention to developing methods to support the reconstruction process in El Salvador. At the same time they found themselves adjusting to the changing circumstances, needs and demands of Salvadoran immigrants. CARECEN and El Rescate in Los Angeles and Washington, DC, faced the challenge of addressing the needs of a more settled but still impoverished and disenfranchised population, while still playing a role in the economic and political life of El Salvador.

As part of this dual agenda, El Rescate and CARECEN have initiated transnational projects that capitalize on their experience as advocates and transnational brokers between El Salvador and politically active Salvadoran migrants. El Rescate has sponsored the creation of a community development credit union in Los Angeles that has several objectives including: 1) to serve as a vehicle for economic development in Los Angeles by facilitating small business loans to Salvadoran entrepreneurs; 2) to serve as a channel for mobilizing and transferring migrants' remittances to El Salvador; and 3) through a partner institution in El Salvador, to play a role in local development in El Salvador. Likewise, CARECEN has initiated a pilot programme called Learning Across Borders as a vehicle for exchange between students, universities, businesses and other organizations in Los Angeles and El Salvador. CARECEN hopes to prepare a generation of socially and politically conscious transnational leaders who can advise investors, organizations, or other entrepreneurs on how to plug into El Salvador's fertile transnational network of markets and communities according to principles of social responsibility.

The home town association or comite de pueblo is one of two types of autonomous transnational civic groups that has proliferated since the end of the war. We estimate that there are now over seventy home town associations in Los Angeles and approximately fifteen such groups in the Washington, DC, area. They are typically formed by a heterogeneous group of migrants from the same place of origin whose self-designated task is to organize social and cultural events in the US to raise funds for improvement projects in the members' place of origin. A comite can raise anywhere between $\$ 5000$ and $\$ 50,000$ in cash and kind to undertake a wide variety of projects such as paving roads, installing electricity, building a war memorial, rebuilding the town plaza, church or playground, supplying the health clinic, or donating an ambulance to the local Red Cross. In the process of undertaking projects, association members create opportunities to reach out not only to their home town but also to their compatriots in the US. In this way, comites build broad social networks among migrants, and also reinforce and institutionalize cultural, economic and political ties with their place of origin.

Comites assume a variety of organizational forms and sustain a wide 
range of transnational relations that are essential for undertaking and completing projects. An association can encompass multiple bureaucratic chapters coordinated across several US cities or involve simply an informal group of compadres who meet periodically to fulfil a conjunctural request from their home town. Their core membership can range in size from five to twenty-five people. Larger, more institutionalized associations endeavour to maintain a regular presence in their town either through a sister comite or by recruiting a trusted individual to oversee projects. Associations may also build relationships with and channel funds through long-standing institutions like the local church or Casa de la Cultura.

In the United States, and specifically in Los Angeles, cross-institutional links have also been forged by home town associations. El Rescate, one of the social justice organizations with an FMLN past, was quick to identify the overlap between its own agenda and that of many of the emerging comites in Los Angeles. As such, El Rescate was instrumental in the formation of and support for the Communities United to Provide Direct Aid to El Salvador [COMUNIDADES] - a coalition of over fifty home town associations that coordinate and support each other's efforts. In turn, links have also been forged between COMUNIDADES and the transnational credit union now in formation. The hope is that this credit union will be the vehicle through which the home town associations of Los Angeles will channel their resources to El Salvador.

The second category of transnational civic associations includes a growing number of immigrant groups whose agenda reflects, first and foremost, the members' vision of themselves as Salvadoran-Americans. Working from the premise that Salvadorans are destined to settle in the US, Salvadoran-American associations focus their efforts on several projects including: 1) educating Salvadorans, regardless of whether they are undocumented, on a temporary work permit, permanent residents, or citizens, of their rights and responsibilities in the US and El Salvador; 2) lobbying local politicians on issues that concern any low-income immigrant community such as public education and immigration policy; and, 3) orienting the Salvadoran government's own lobby of the US federal government, again, on migration issues.

In their struggle to improve the standing of the Salvadoran population in the US, groups employ a variety of overlapping local and transnational strategies. Maximizing their limited material resources, these small organizations successfully mobilize large segments of the Salvadoran population for vocal public demonstrations. They have also joined forces with partisan groups including CARECEN to create the SalvadoranAmerican National Network [SANN]. The SANN encourages dialogue among groups, coordinates national-level campaigns, provides updates on policy issues, and serves as a critical interlocutor between the 


\section{8}

community-based organizations and both the Salvadoran government and El Salvador's ombuds office, specifically its international migration and migrant rights department.

Going beyond the obvious differences in their agenda, a critical distinction between the two types of autonomous transnational civic associations is their respective views about the world of politics. While at some level both groups assume that organized collective action, a cornerstone of political mobilization, is an effective mode of engagement in social process, their evaluation of partisan politics and political process in general is quite different. The home town associations reject the idea that they are political actors, whereas Salvadoran-American groups cultivate their image as effective and legitimate political representatives of the immigrant population.

While the negative evaluation of politics varies across groups and between cities, the overwhelming majority of home town associations not only distrust politicians and maintain a cautious distance from political institutions, especially those of their home town, they also refuse to see themselves as political actors. In spite of their self-professed neutrality and their emphasis on the humanitarian nature of their agenda, the home town association is a political actor. A comite's actions have the potential to reinforce or challenge the status quo and influence the course of local development depending, for instance, on which projects they choose to support and with whom they cooperate. Associations also become politicized, since their presence in El Salvador and in Salvadoran settlements abroad incites local and transnational political responses from both municipal authorities and the national government of El Salvador. For instance, mayors in El Salvador often either attempt to take credit for and gain political mileage from projects financed by home town associations, or try to undermine, or even sabotage, the work of the association when they perceive that it upstages their own work.

In contrast, Salvadoran-American groups support the transnational lobbying efforts of SANN, and actively cultivate working relations both with the partisan associations and local politicians in the US who are sympathetic to their concerns. They seek to influence political process in the short term and consider it their responsibility to educate their constituency to be proactive and to become politically aware citizens. Their innovative methods combine the tactics of mainstream US politics (lobbying and policy education) with the grass-roots tradition of popular education associated with the work of Paulo Freire and the practice of El Salvador's progressive church elements.

Together the transnational initiatives of Salvadoran migrants embody a hopeful project for El Salvador's post-war reconstruction and reconciliation. In spite of their varied agendas and strategies, all groups exhibit a great willingness to collaborate on issues of mutual concern. More importantly, organizations endeavour to promote tolerance and 
flexibility within their own institution. Association leaders emphasize the need to build institutions that are dynamic enough to incorporate varying opinions and views on any given subject. This spirit of tolerance within groups and the promotion of inter-institutional collaboration is effectively eroding the migrant population's fear of participation and their distrust of organized collective action.

\section{Old actors/new strategies: the transnational establishment}

The Peace Accords forced both the right and the left in Salvadoran politics to overhaul their respective modus operandi-impunity and guerilla strategy were exchanged for electoral party platforms and dialogue. As part of this political transition, both sectors have reconfigured their mode of engagement with El Salvador's migrant-citizens. In this section, we examine the transnational practices, policies and programmes of the government of El Salvador and the FMLN.

In recent years, the Salvadoran government's position towards the expatriate community has changed dramatically. Through its consulates, embassies and other institutions, it is now actively reaching out to those it regarded as the enemy not long ago. In 1994 the ARENA government of Calderon Sol launched a consular programme that includes several initiates such as legal services for undocumented Salvadorans, public celebrations of religious festivals and national holidays, business meetings with prominent Salvadoran entrepreneurs, visits by government representatives, and a campaign to inform Salvadorans of their rights as citizens of El Salvador. As the consul in Los Angeles proclaimed, 'Our role as civil servants is to not allow, under any circumstances, the loss of the umbilical cord between Salvadorans and their country of origin'.

Government ministries based in El Salvador have also developed transnational political strategies to secure the ongoing cultural identification, political allegiance and economic support of the migrant population. One of the most visible of these transnational initiatives involves the Consejo Nacional para la Cultura y el Arte [CONCULTURA], an agency of the Ministry of Education that oversees the activities of the 115 Casas de la Cultura or cultural centres in El Salvador whose mission is to preserve and promote Salvadoran culture. In an unprecedented move, CONCULTURA, in conjunction with the local branch of the CCIS and the consulate, opened a Casa de la Cultura in Los Angeles. Since its founding in 1996, the Los Angeles Casa de la Cultura has advertised among home town associations as a space where they can meet and plan their activities. According to a government representative in San Salvador, the long-term goal is to encourage home town associations to channel resources through CONCULTURA in Los Angeles to the Casa de la Cultura in their town of origin.

The government has identified Salvadoran settlements abroad as an 


\section{0}

important arena of political struggle. Its consular programmes, since they duplicate the services and advocacy role of community-based organizations traditionally associated with the FMLN, can be seen as a strategy of co-optation. The similarities between CONCULTURA's project for home town associations and that of COMUNIDADES also suggest competition and co-optation. The transnational strategies of the government are significant because, albeit highly problematic and top-down, they signal a space for contact, and potentially for dialogue, between social sectors - El Salvador's élites and the uprooted - that have historically only sustained a relationship rooted in violence.

In stark contrast to the government's current transnational practices and to its own war-time transnationalism, the FMLN's sphere of transnational influence and concern is profoundly limited. Facing the challenge of electoral politics and a critical shortage of resources, the FMLN turned inward in 1992. It dismantled its global network of political representatives and granted autonomy to national and international affiliated organizations. Its presence in Salvadoran settlements abroad, once ubiquitous, was reduced to highly personalized connections with former militants, the transformation of formerly clandestine FMLN Committees into open political organizations, and occasional visits from the FMLN's recently elected representatives. In August 1997 the FMLN held a convention in San Francisco, CA. Items on the agenda included full party membership and representation for FMLN activists in the US and migrant-citizens right to vote in national elections. Given the volatility of these issues, the FMLN resolved to survey the migrant population in various US cities before making a decision. To date, the push for sustaining the FMLN's transnational ties has come from FMLN militants in the US.

Table 2 summarizes the discussion of the four types of grass-roots and élite political practices that link El Salvador and its migrant-citizens. The four types of transnational political practices identified include: partisan groups, autonomous-political organizations and autonomous apoliticalorganizations, and the programmes and strategies of El Salvador's established political actors. Unlike the more straightforward typology of transnational economic enterprises, the classification scheme of political transnationalism was inductively culled from the empirical discussion and merits explanation.

The typology emphasizes the institutional dimensions of these transnational practices including: the ideological origins of the organization, and the location of its constituency and collaborators and its target for change. Most significantly, there is a clear tendency across all organizations to cultivate both local and transnational alliances and collaborative arrangements. The growing institution al links and overlaps between these new transnational political projects, particularly within the immigrant population, inevitably bring a wide array of Salvadorans into 
Salvadoran transnationalism 311

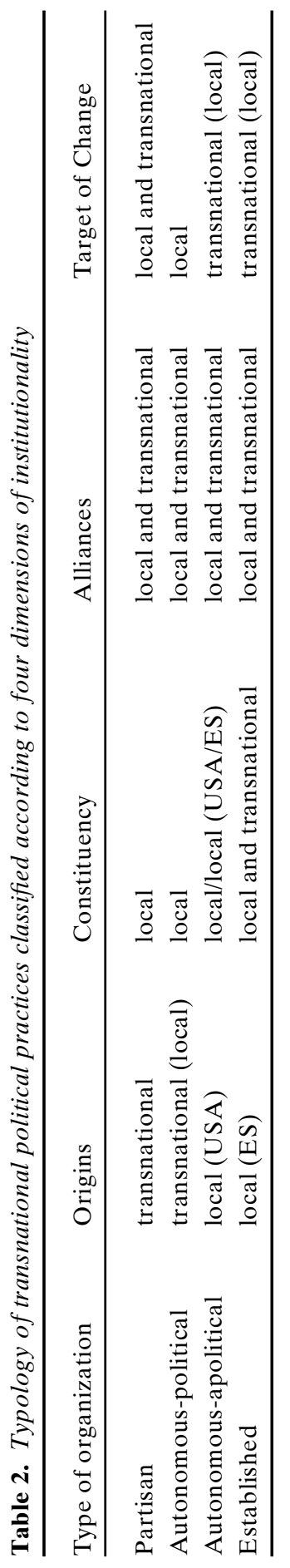




\section{Patricia Landolt et al.}

contact with each other. In this process, key actors from diverse backgrounds are recognizing and interacting with one another and at some level are beginning to speak a common political language in tune with their reality as transnational migrant-citizens.

The transnational strategies of El Salvador's political establishment, like those of the Salvadoran migrant grass roots, reflect a desire for rapprochement and collaboration across the political and class divisions that have historically divided Salvadorans. Yet, in contrast to the projects of the Salvadoran grass roots, the programmes of the government and the FMLN pay scant attention to the construction of new channels for dialogue and institutional representation. There is a sense among Salvadoran migrants that the political establishment, and particularly the government of El Salvador, is concerned above all with maintaining a passive transnational relationship that will guarantee the flow of remittance dollars into El Salvador. In contrast, Salvadoran migrants are united in their recognition of migrants as an important actor with a role to play in the future of El Salvador. Indeed, Salvadoran migrants suggest that in order to sustain the relationship of loyalty or the umbilical chord that currently exists between Salvadoran migrants and their places of origin, El Salvador's established actors will have to do more than recognize the impact of migrants on national affairs. More mechanisms and channels for migrant-citizen participation and institutional representation are in order. Their character will be determined in large measure by the extent to which migrants are able to constitute an organized and unified political voice.

\section{Conclusion}

This article set out to test the general proposition that the construction of a transnational social sphere results from the dialectical engage ment of a nation's grass roots and élites. Salvadoran transnationalism with its rich diversity of transnational practices and processes bears out this proposition. Motivated by a deep sense of obligation, Salvadoran migrants first forged household-level transnational relations that had a massive aggregate impact on their places of origin and elicited spontaneous and institutional responses from Salvadoran society. These first transnational forays centred by and large on economic affairs. Yet Salvadoran migrants' transnational practices quickly extended beyond the bounds of the household. As transnational economic enterprises and political projects blossomed, they elicited more focused and strategic responses from institutions and power holders in El Salvador. In effect, the case of Salvadoran transnationalism suggests that the transnational engagement of grass roots and élites has cumulative transformatory effects because each exchange and interaction appears to sharpen the transnational acumen for dialogue, competition, collaboration, and 
co-optation of all the players. As such, the transnational social field, which first emerges as an indeterminate social space, quickly becomes a contested terrain of action in which the displaced search for survival and demand social recognition and the powerful scramble to control the transnational flow of resources and reimpose their dominion.

The Salvadoran migration process shares many features with other contemporary migration flows. Yet, the particular combination of factors that have moulded Salvadoran transnationalism is quite unique. Like other Caribbean Basin countries, El Salvador had an established tradition of regional labour migration that in the economic crisis of the 1980s spilled over into the United States. But El Salvador is the only country in the region that waged a civil war on a transnational stage. It is this element that has conditioned every sphere of Salvadoran transnationalism including migrants' rapid and massive flight from El Salvador and their hostile reception in the United States, the high degree of politicization among certain sectors of the migrant population and the deep-rooted fear of politics among others, the Salvadoran government's mistrust of migrants and later their keen interest in co-opting migrants' autonomous political projects. Hence, the particularities of Salvadoran transnationalism are largely explained by the socio-political conjuncture in which transnational practices first emerged on a large scale and were consolidated.

Finally, the case-study of El Salvador sheds light on at least three patterns that are relevant for a more general understanding of transnationalism. First, given a global context propitious to the maintenance of transnational ties, the conditions of migrants' exit from their country of origin and their reception in the host society have a critical impact on their propensity towards transnationalism. In this light, a transnational frame of reference is required not only for analysing contemporary immigrant settlement outcomes but also for re-defining the concept of settlement itself. Second, the two typologies of transnational economic enterprises and transnational political practices serve as a starting point for a comparative dialogue of transnationalism. Reviewing our discussion, factors that have a direct influence on the character of organized transnational activities include: the size of the economy of the country of origin and its institutional rigidity or flexibility; the quality of resources of the migrant population; the nature of the political regime of the country of origin including the strength, stability and resources of the state. These elements shape the weight that the impact of migrant transnationalism has on the country of origin, and the capacity of different sectors of the sending society to respond in various ways to the transnational practices and processes being initiated by the migrant population. 


\section{Patricia Landolt et al.}

\section{Note}

1. In 1996 fifty guided interviews were conducted with key informants in Los Angeles and Washington, DC. This was followed with fieldwork in El Salvador, where guided interviews were conducted in San Salvador, San Miguel and a dozen small municipios in the four departments that comprise the war-torn region known as oriente.

\section{References}

BAIRES, SONIA and INNOCENTI, GIANFRANCO 1993 Migrantes, Remesas y Desarollo Micro Empresarial en El Salvador, San Salvador: Universidad CentroamericanaJosé Simeon $\mathrm{Ca}$ as

BASCH, LINDA et al. 1994 Nations Unbound: Transnational Projects, Postcolonial Predicaments and Deterritorialized Nation-States, Langhorne, PA: Gordon and Breach

BROWNING, DAVID 1971 El Salvador: Landscape and Society, Oxford: Oxford University Press

CARIBBEAN UPDATE 1996 'El Salvador: Balance of Payments on Target', 1 October ECLA 1993 'El impacto económico y social de las migraciones en Centroamérica', Estudios e Informes de la CEPAL, vol. 89, pp. 25-54

GLICK SCHILLER, NINA et al. 1992 Towards a Transnational Perspective on Migration: Race, Class, Ethnicity and Nationalism Reconsidered, New York: The New York Academy of Sciences

GOSSE, VAN 1996 'El Salvador is Spanish for Vietnam: a new immigrant left and the politics of solidarity', in Paul Buhle and Dan Georgakas (eds), The Immigrant Left in the United States, Albany, NY: State University of New York, pp. 302-30

GUARNIZO, LUIS E. and SMITH, MICHAEL P. 1998 'The locations of transnationalism', in Michael Peter Smith and Luis E. Guarnizo (eds), Transnationalism from Below, New Brunswick, NJ: Transaction Publishers

HAMILTON, NORA and CHINCHILLA, NORMA STOLZ 1991 'Central American migration: a framework for analysis', Latin American Research Review, vol. 26, no. 1, pp. 75-110

HARVEY, DAVID 1989 The Condition of Postmodernity: An Enquiry into the Origins of Cultural Change, Cambridge, MA: Blackwell

LOPEZ, DAVID et al. 1996 'Central Americans: at the bottom, struggling to get ahead', in Roger Waldinger and Mehdi Bozorgmehr (eds), Ethnic Los Angeles, New York: Russell Sage Foundation, pp. 279-304

MAHLER, SARAH 1995 American Dreaming: Immigrant Life on the Margins, Princeton, NJ: Princeton University Press

MERTON, ROBERT 1984 'Socially expected durations: a case study of concept formation in sociology', in W. W. Powell and Richard Robbins (eds), Conflict and Consensus: A Festschrift for Lewis A. Coser, New York: The Free Press, pp. 262-86

NAGENGAST, CAROLE and KEARNEY, M. 1990 'Mixtex ethnicity: social identity, political consciousness and political activism', Latin American Research Review, vol. 73, no. 25, pp. 61-91

PORTES, ALEJANDRO 1995 'Transnational Communities: Their Emergence and Significance in the Contemporary World System', Working Paper Series of the Programme in Comparative International Development No.16 Baltimore, MD: The Johns Hopkins University

PORTES, ALEJANDRO and RUMBAUT, R. 1997 Immigrant America: A Portrait Berkeley, CA: University of California Press

REPAK, TERRY 1995 Waiting on Washington: Central American Workers in the Nation's Capital, Philadelphia, PA: Temple University Press

ROBERTS, BRYAN 1995 'Socially expected durations and the economic adjustment of 
immigrants', in Alejandro Portes (ed.), The Economic Sociology of Immigration: Essays on Networks, Ethnicity and Entrepreneurship, New York: Russell Sage Foundation, pp. 42-87 ROUSE, ROGER 1991 'Mexican migrants and the social space of postmodernism', Diaspora, vol. 1, no. 1, pp. 8-23

STANTON-RUSSELL, SHARON 1995 'Migration patterns of U.S. foreign policy interests', in Michael S. Teitelbaum and Myron Weiner (eds), Threatened Peoples, Threatened Borders: World Migration \& U.S. Policy, New York: W. W. Norton \& Company, pp. $39-87$

US BUREAU OF THE CENSUS 1992 Census of Population, General Social and Economic Characteristics, D.C. Report, Washington, DC: US Government Printing Office VITTORIO, CAPECCHI 1989 'The informal economy and the development of flexible specialization in Emilia-Romagna', in Alejandro Portes et al. (eds), The Informal Economy: Studies in Advanced and Less Developed Countries, Baltimore, MD: The Johns Hopkins University Press, pp.189-215

ZLOTNIK, HANIA 1996 'Policies and migration trends in the North American system', in Alan Simmons (ed.), International Migration, Refugee Flows and Human Rights in North America: The Impact of Trade and Restructuring, New York: The Center for Migration Studies, pp. 50-76

ZOLBERG, ARISTIDE et al. 1989 Escape From Violence: Conflict and the Refugee Crisis in the Developing World, New York: Oxford University Press

PATRICIA LANDOLT is a doctoral candidate in the Department of Sociology at The Johns Hopkins University.

ADDRESS: Dept. of Sociology, The Johns Hopkins University, 3400 N. Charles St., Baltimore, MD 21218, U.S.A.

LILIAN AUTLER has a master's degree in Urban Planning from the University of California, Los Angeles. She works as a writer and community development planner in Oakland, California.

SONIA BAIRES is a doctoral student in the joint programme of Urban Studies at the University of Québec in Montréal and the Institute for Scientific Research.

ADDRESS: INRS-URBANISATION, 3465 rue Durocher, Montréal, Quebec H2X 2C6, Canada. 